\title{
Insights into granulosa cell tumors using spontaneous or genetically engineered mouse models
}

\section{So-Youn Kim}

Division of Reproductive Science in Medicine, Department of Obstetrics and Gynecology, Feinberg School of Medicine, Northwestern University, Chicago, LL, USA

Granulosa cell tumors (GCTs) are rare sex cord-stromal tumors that have been studied for decades. However, their infrequency has delayed efforts to research their etiology. Recently, mutations in human GCTs have been discovered, which has led to further research aimed at determining the molecular mechanisms underlying the disease. Mouse models have been important tools for studying GCTs, and have provided means to develop and improve diagnostics and therapeutics. Thus far, several genetically modified mouse models, along with one spontaneous mouse model, have been reported. This review summarizes the phenotypes of these mouse models and their applicability in elucidating the mechanisms of granulosa cell tumor development.

Keywords: Adult granulosa cell tumor; Animal Models; Granulosa cell tumor; Juvenile granulosa cell tumor

\section{Introduction}

Granulosa cell tumors (GCTs) are sex cord-stromal tumors that comprise $5 \%$ of all ovarian tumors in women [1,2]. Although GCTs arise mainly from granulosa cells, they can develop in both the ovaries in women and the testes in men $[3,4]$. GCTs are usually detectable at an early stage; however, $43 \%$ of patients experience recurrence, and $80 \%$ of those patients die from the disease $[5,6]$. Due to the indolent nature of these tumors, along with their propensity for relapse and malignan-

Received: Jan 25, 2016 · Revised: Feb 24, 2016 · Accepted: Mar 4, 2016 Corresponding author: So-Youn Kim

Division of Reproductive Science in Medicine, Feinberg School of Medicine, Northwestern University, Lurie Building 10-250, 303 East Superior Street, Chicago, IL 60611, USA

Tel: +1-312-503-2530 Fax: +1-312-503-0219E-mail: so-youn-kim@northwestern.edu

*This work was supported by the Center for Reproductive Health After Disease (P50HD076188) from the National Institutes of Health National Center for Translational Research in Reproduction and Infertility (NCTRI) and the Granulosa Cell Tumour Research Foundation (GCTRF).

This is an Open Access article distributed under the terms of the Creative Commons Attribution Non-Commercial License (http://creativecommons.org/licenses/by-nc/3.0/) which permits unrestricted non-commercial use, distribution, and reproduction in any medium, provided the original work is properly cited. cy, patients with GCTs need long-term follow-up to monitor whether recurrence or metastasis has occurred $[7,8]$. Inhibins have been used as reliable markers to diagnose GCT recurrence and progression [9-11].

GCTs are classified into juvenile granulosa cell tumors (JGCTs) and adult granulosa cell tumors (AGCTs) based on histology, nuclear morphology, the age of occurrence, and the potential for disease recurrence. AGCTs are the most common type of GCT, and occur in periand postmenopausal women [12]. JGCTs occur in girls from infancy through puberty and have the potential for malignancy [7]. AGCTs often show prominent nuclear and histological features, such as nuclear grooves (coffee-bean nuclei) and Call-Exner bodies (small fluidfilled spaces surrounded by granulosa cells). By contrast, granulosa cells in JGCTs are neoplastic, round, non-grooved, luteinized, and have hyperchromatic nuclei [13]. Moreover, histological analysis shows the presence of follicle-like spaces in JGCTs.

Advances in the identification of molecular mechanisms implicated in AGCTs have identified the C402G missense mutation of the FOXL2 gene as present in $95 \%$ of AGCT patients $[14,15]$. This mutation has not been found in JGCTS, and, furthermore, the loss of FOXL2 expression has been observed in aggressive JGCTs [16]. The absence of 
FOXL2 can alter the fate of granulosa cells, pushing them into uncontrolled growth, because FOXL2 expression is important for establishing and maintaining granulosa cell identity. The FOXL2 ${ }^{\mathrm{C} 134 W}$ mutation may induce AGCT formation by regulating targets in apoptotic [17] and steroidogenic [18] pathways. However, no clear pathophysiological mechanisms have been described. While FOXL2 mutations in other loci induce mislocalization, protein aggregation, and impaired transactivation [19], the C402G missense mutation of the FOXL2 gene does not lead to alterations in FOLX2 protein subcellular localization, protein aggregation, mobility, or transactivational activity on its target promoter in vitro compared to wild-type protein FOLX2 [20]. Recently, it was proposed that GSK3 $\beta$ regulation on serine 33 (S33) of mutant FOXL2 is the cause of oncogenicity in AGCT [21]. Two activating mutations (R201C and R201H) of the stimulatory a subunit of a trimetric G protein (Gas) were discovered in JGCT patients [22], and in-frame duplications within the pleckstrin homology domain of AKT1 were discovered in $>60 \%$ of JGCT patients [23].

Two cell lines derived from human GCTs have been investigated to understand the etiology and molecular mechanisms of AGCTs and JGCTs $[24,25]$. Despite the important information that has been obtained using these cell lines, some discordances have been observed with data obtained from studies of human tumors [26], suggesting that the use of mouse models for studying GCTs may be necessary to more fully understand their origins. Here, we summarize the phenotypes of the currently available GCT mouse models and what they have revealed about the molecular mechanisms underlying GCT development.

\section{SWR mice}

SWR/Bm (SWR) mice were reported in 1985 as a model for studying pathways leading to the formation of spontaneous JGCTs [27]. Approximately $1 \%$ of inbred female SWR mice develop malignant JGCTs at approximately 8 weeks of age, starting at the time of the first ovarian follicle maturation at approximately 3 to 5 weeks of age [28]. Possible tumor susceptibility modifiers include the Gct loci, such as Gct1 on chromosome 4 and Gct4 and Gct6 on the X chromosome. Gct1 is essential for GCT development and is responsive to the androgenic precursor dehydroepiandrosterone, which has been shown to increase tumor frequency [29]. Although other foci such as Gct2, Gct3, Gct4, Gct5, Gct6, Gct7, Gct8, and Gct9 are also linked with Gct1 and may be associated with the formation of GCTs, the Gct $1^{S W}$ allele is an essential driver for the ovarian tumor phenotype [30]. Four genes within the Gct1 interval (Vps13d, Tnfrsf8, Tnfrsf1b, and Dhrs3) may be involved in tumor formation in SWR mice. The tumors in this model are endocrinologically active, secreting high levels of inhibin and estrogen [29]. The initial formation of spontaneous GCTs is dependent on endocrine hormones, such as androgenic steroids at puberty, im- plying that the time frame of the first wave of maturing follicles is critical in the development of JGCTs. GCTs from SWR mice have neoplastic potential, as demonstrated by the incidence of metastases through consecutive transplantation. SWR mice have significantly decreased serum levels of follicle-stimulating hormone (FSH) and luteinizing hormone (LH), as seen in human GCT patients, while inhibin-a is robustly increased [31]. The serum levels of progesterone, dihydrotestosterone, and testosterone are also reduced in SWR mice, while tumor-bearing mice have a high capacity for aromatization. Therefore, this mouse model has similar histological and endocrine characteristics to human JGCT patients.

\section{Inhibin-a null mice}

The inhibins belong to members of the transforming growth factor- $\beta$ (TGF- $\beta$ ) family and inhibit the synthesis and secretion of pituitary FSH [32,33]. These peptide hormones are expressed in the adrenal gland, pituitary, brain, spleen, kidney, central nervous system, placenta, and the gonads [32]. Targeted deletion of the Inha gene causes the development of gonadal stromal tumors as early as 4 weeks of age in both males and females, with nearly $100 \%$ penetrance [34]. Female mice develop multifocal, hemorrhagic, bilateral tumors with tubular or cord-like structures. Comparison of the serum FSH levels in these Inha-null mice shows a two- to threefold increase compared to heterozygous or wild-type controls, a characteristic that is secondary to the lack of suppression by inhibin. This suggests that downstream molecules in the inhibin signaling pathway are important for GCT formation, and imbalances in gonadotropins might also play a role [35]. As shown in follitropin receptor knockout (FORKO) mice [36], perturbations in the gonadotropin signaling pathway and milieu of the ovary induce the development of GCTs. FORKO mice have a high serum level of activin secreted from the ovarian tumor, resulting in a cachexia-like wasting syndrome that is lethal to the mice at the onset of ovarian tumor development $[34,37]$.

High levels of activin caused by elimination of the Inha gene induce activation of the SMAD2/3 signaling pathway in granulosa cells, stimulating proliferation [34]. The importance of SMAD3 for tumor progression is supported by studies of Madh3-/- (SMAD3-null) and Inha double knockout mice, which show slower progression of GCTs; SMAD2 is not necessary for inducing tumor formation in inhibin-deficient mice [38-40]. Although inhibin-a null mice develop GCTs, their relevance for human GCTs is not completely understood because the majority of human GCT patients have high serum levels of inhibins $[41,42]$. Nonetheless, this mouse model has been useful for understanding the downstream molecular pathways of GCT formation.

\section{Mice with the simian virus $40 \mathrm{~T}$-antigen fusion gene}

Simian virus $40 \mathrm{~T}$-antigen is a proto-oncogene that can transform 
cells. Transgenic mice with overexpression of the simian virus $40 \mathrm{~T}-$ antigen driven by the murine inhibin-a subunit promoter (Inha/Tag) were originally developed as a source of granulosa tumor cell lines to investigate the characteristics of GCTs. The ovarian tumors from these mice are prominent at 5 to 6 months of age and have 100\% penetrance [43]. Tumor cells from these mice are atypical, mitotic, and have the appearance of granulosa cells, though the tumor cells cannot be classified as AGCT or JGCT. Additionally, a transgenic mouse line with overexpression of simian virus 40 T-antigen driven by the anti-Müllerian hormone (AMH) promoter also develops ovarian tumors [44]. The ovarian tumors are bilateral, with $10 \%$ of mice developing tumors at 3 to 8 months of age. These mouse ovarian tumors contain serous cystic spaces, large hemorrhages, and necrosis, showing further metastases in the lungs or liver in later stages. Cell lines derived from these mice maintain granulosa cell characteristics, such as the expression of $\mathrm{LH}$, production of estradiol, responsiveness to human chorionic gonadotropin (hCG), and the presence of granulosa cell markers, as well as AMH type II receptors [44].

\section{Mice with overexpression of the LH $\beta$ subunit (bLH $\beta-\mathrm{COOH}$ - terminal peptide)}

These mice were generated using bovine LH $\beta$-subunit/hCG $\beta$-subunit $\mathrm{COOH}$-terminal peptide (bLH $\beta$-CTP) [45]. Tumorigenesis in these mice occurs at 4 to 8 months of age. These transgenic mice show unusually high levels of $L H$, as well as precocious puberty, a prolonged luteal phase, formation of cysts and, thus, GCTs, causing infertility in transgenic female mice dependent on their genetic predisposition [46]. High levels of estradiol, testosterone, and progesterone are present, and LH is especially high, suggesting that elevated LH might contribute to the formation of GCTs. According to a report describing the crystal structure of hCG [47], LH has growth factor-like properties. Excessive levels of $\mathrm{LH}$ in transgenic mice result in angiogenesis and growth aberrations, indicating that abnormal gonadotropin stimulation is tumorigenic. However, these mice have many unique non-gonadal phenotypes due to chronically elevated steroid levels. The importance of excessive LH in inducing tumor formation is also supported by mice deficient in both inhibins and LH [48]. These mice show a delay in tumor progression and increased survival. Moreover, bLH $\beta$-CTP and Inha/Tag double transgenic mice show much faster gonadal tumorigenesis with elevated serum levels of LH [49]. Altogether, these mice models indicate that excessive LH levels can induce tumor formation.

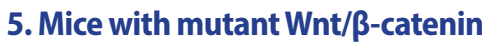

Ovarian granulosa cells express components of the $\mathrm{Wnt} / \beta$-catenin pathway, suggesting that $\mathrm{Wnt} / \beta$-catenin (CTNNB1) plays a role in granulosa cells. More specifically, both human and equine GCTs show nuclear localization of $\beta$-catenin. The PI3K/AKT signaling pathway can also activate the WNT/CTNNB1 pathway through inactivation

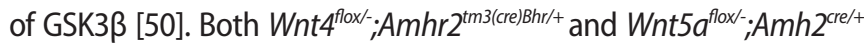
mice are subfertile and have small ovaries, follicle atresia, and a decreased ovulation rate, indicating that the WNT signaling pathway is important in ovarian follicle growth/survival and steroidogenesis [51-

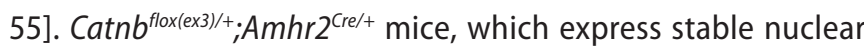
$\beta$-catenin driven by the Amhr2 promoter, develop GCTs, suggesting the importance of the misregulated Wnt/ $\beta$-catenin pathway in GCT development [56]. Follicle-like structures develop at 6 weeks of age, and in $57 \%$ of mice, the formation of GCTs occurs at 7 months. A microarray analysis of pretumoral aged mice showed high expression levels of Wnt/ $\beta$-catenin antagonists and neuronal markers. These were localized in pretumoral lesions, implying that the misregulated Wnt/ $\beta$-catenin signaling pathway changes the fate of granulosa cells

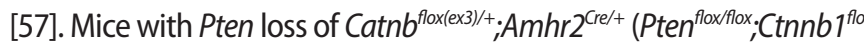
${ }^{x\left(x^{2} 3\right) /+} ; A m h 2^{(\text {ree/ }+)}$ demonstrate quickly growing GCTs with the ability to spread into the abdominal cavity, suggesting that PI3K/AKT and WNT/CTNNB1 signaling have synergistic effects in the development

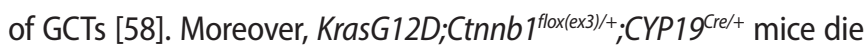

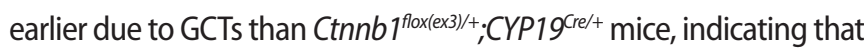
the KRAS pathway is involved in GCT formation [4]. Therefore, misregulated WNT signaling in granulosa cells can affect cell development and the formation of GCTs.

\section{Double conditional knockout mice of SMAD1 and SMAD5 in granulosa cells}

Female mice deficient in both Smad1 and Smad5 in granulosa cells using Amhr2-cre are subfertile and develop GCTs with $100 \%$ penetrance [59]. This mouse model shows a phenotype at 2 to 3 months that is similar to that of humans with JGCTs [60]. Furthermore, $80 \%$ of these mice develop peritoneal and lymphatic metastases by 8 months of age [59]. This mouse model suggests that a signaling pathway involving the activation of SMAD2/3 or the disruption of SMAD1/5 is conducive to JGCT pathogenesis. SMAD1/5 double-knockout mice had lower serum levels of FSH and altered LH and estradiol levels than control animals. Moreover, serum levels of inhibin- $\alpha$ and $A M H$ are highly elevated in this mouse model. WNT/ $\beta$-catenin in SMAD1/5 double-knockout mice is not significantly different from that observed in wild-type mice, suggesting that WNT/ $\beta$-catenin may not contribute to JGCTs in the SMAD1/5 mouse model. Recent reports have demonstrated that TGF $\beta$-SMAD signaling contributes to JGCT development through a study of Smad1/5/4 triple-knockout mice, which were found to exhibit delayed tumor formation and no evidence of metastasis, in contrast to Smad1/5 double-knockout mice [61]. These findings suggest that the TGF $\beta$ signaling pathway contributes to tumor formation in JGCTs through the repression of apoptosis. 


\section{Mice with double-mutant BMPR1A and BMPR1B in granulosa cells}

The BMP signaling pathway is important for granulosa cell development. Among the type I receptors of the BMP signaling pathway, $\mathrm{BMP}$ receptors $1 \mathrm{~A}$ and $1 \mathrm{~B}$ are expressed in granulosa cells [62], and the knockout of both genes results in GCTs [63]. Tumors from Bmpr1a/1b double-knockout mice show upregulated TGF $\beta$ and TGF $\beta$ target genes. The ovaries of Bmpr $1 a / 1 b$ double-knockout mice develop bilateral ovarian tumors from $8(\leq 40 \%), 16(\leq 90 \%)$ months of age. The gene expression profiles of ovarian tumors of Bmpr1a/1b double-knockout mice are similar to those of Smad1/5 doubleknockout mice tumors, although some differences between the two exist. This implies that the BMP signaling pathway through the BMP ligands, $B M P R 1 A / 1 B$ to $S M A D 1 / 5$, is important for the regulation of tumor suppressor pathways in mouse granulosa cells.

\section{Estrogen receptor- $\beta$ knockout mice}

Pituitary and ovarian tumors are observed in estrogen receptor (ER)- $\beta$ knockout mice female mice at 2 years of age. GCTs in ER $\beta-/-$ mice secrete estrogen and have high expression of ERa [64]. Pituitary tumors induce the high expression of gonadotropin-releasing hormone, which consequently causes the proliferation of granulosa cells, as well as endometrial hyperplasia, resulting in ovarian tumors [64]. Regarding the role of ERa in ovarian tumor formation, Couse and Korach [65] showed that $40 \%$ of $E R a / \beta$ double-knockout female mice developed sex cord-stromal ovarian tumors between 15 and 20 months of age. However, Fan et al. [64] showed that ERa/ $\beta$ doubleknockout female mice did not develop ovarian tumors, emphasizing the necessity of ERa in the development of GCTs. Consistent with this observation, female ERa-/- and Inha-/- double-knockout mice show an enhanced onset of GCT formation, shorter survival, and induced hypergonadotropism caused by disruption of the negative feedback mechanism in the absence of ERa [66]. Burns et al. [66] also showed that ERa was the genetic modifier involved in the development of ovarian tumors using $E R a / I n h a$ double-knockout mice and $E R a / \beta$ / Inha triple-knockout mice. However, the survival curves for $E R \beta / I n-$ hadouble-knockout mice overlapped with those of Inha mice, indicating that $E R \beta$ alone is not enough to induce tumor formation. High expression of the LH receptor and SMAD3 are seen in both ER $\beta /$ Inha double-knockout and inhibin-a knockout mice. Therefore, ER signaling pathways may have protective effects on tumor formation in females, with acceleration of tumor formation upon mutations in the ERa locus and the loss of both ERa and ERß.

\section{Mice with depletion of Foxo1/3 and Pten}

The selective inactivation of the Foxo 1 and Foxo3 genes in mouse ovarian granulosa cells leads to the development of GCTs in $\leq 20 \%$ of Foxo $1 / 3$ double knockout mice by 6 to 8 months of age. Although Pten conditional knockout mice with loss of the Pten gene in granulosa cells (Pten ${ }^{f / f}$;Cyp19-Cre) show persistent nonsteroidogenic luteal cells [67], some mice (1\%-7\%) develop GCTs in Pten ${ }^{f / f}$;Amhr2-Cre [58]. Additional inactivation of the Pten gene in the Foxo1/3 strain enhances the onset of GCT formation to $65 \%$ in the Foxo 1/3/Pten tripleknockout mice at approximately 2 to 3 months of age [68], suggesting that the loss of Pten in the Foxo1/3 double knockout mice strain has a synergistic effect, inducing the formation and growth of GCTs. The loss of Foxo1/3/Pten contributes to the formation of GCTs because FOX01/3 in granulosa cells regulates follicular development and apoptosis. This mouse model shows high expression of the FoxI2, Gata4, and Wnt4 genes, similar to what is observed in human GCT patients. Furthermore, the serum hormone profiles, which indicate elevated estradiol levels, high levels of activin (specially, $\beta B$ ) and inhibin, and low serum LH and FSH levels, suggest that the Foxo1/3 double-knockout mice can serve as a model for adult human GCTs. The tumor granulosa cells exhibit high expression of $p-S M A D 2 / 3$ in the nuclei of granulosa cells, indicating that activin/TGF $\beta$ signaling is active in the formation of GCTs.

\section{Oocyte-driven PIK3CA* mice}

This mouse model was generated by crossing mice expressing oocyte-specific Cre-recombinase (GDF9-iCre) [69] with mice expressing constitutively active mutant PI3K (PIK3CA*) [70]. In these mice, the elevation of phosphatidylinositol (3,4,5)-trisphosphate levels within oocytes promotes the survival of follicles and anovulation due to endocrine abnormalities. This mouse model develops GCTs when the mice are mature, at 2 months of age [71]. The hormonal profiles show high levels of activin, inhibin, $\mathrm{AMH}$, testosterone, and progesterone, and low levels of FSH and $\mathrm{LH}$. The molecular signatures of this mouse model include high levels of SMAD3, FOXL2, and GATA4. This mouse might provide a good model for identifying the molecular mechanisms of GCT initiation and formation due to the absence of the mutation in the granulosa cells $[70,71]$.

\section{Conclusion}

Despite significant progress in understanding GCT biology, questions remain regarding the molecular mechanisms of JGCT and AGCT development. Although some mutations that induce the formation of AGCTs and JGCTs have been discovered, the events that initiate tumors and drive recurrence are still unclear. Therefore, suitable models are very important in understanding the molecular pathways underlying GCT formation. In particular, it is important to revisit these mouse models (Table 1) and reassess their characteristics compared to human GCTs based on histopathology, molecular pathways, and 


\begin{tabular}{|c|c|c|c|c|c|c|c|c|c|c|c|}
\hline 莺 & $\sqrt{\beth}$ & $\underset{\substack{\tilde{m} \\
\text { ల్m }}}{ }$ & $\overline{\bar{g}}$ & 胥 & 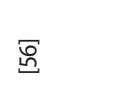 & $\begin{array}{l}\text { 宫 } \\
\text {. }\end{array}$ & $\overline{\bar{\beta}}$ & F & 离 & $\underset{\stackrel{\bar{\Omega}}{\bar{\Omega}}}{\bar{\Sigma}}$ & 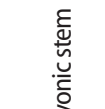 \\
\hline$\sum_{i}^{T}$ & $\frac{\kappa}{z}$ & $\stackrel{\mathbb{1}}{z}$ & $\frac{\kappa}{z}$ & $\frac{\kappa}{z}$ & $\frac{\kappa}{z}$ & 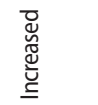 & $\stackrel{\Sigma}{z}$ & $\frac{\kappa}{z}$ & $\frac{1}{z}$ & 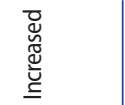 & $\begin{array}{l}\text { है } \\
\underline{\tilde{c}} \\
\underline{\underline{\tilde{E}}}\end{array}$ \\
\hline 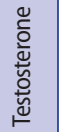 & 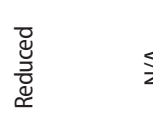 & $\frac{\mathbb{z}}{z}$ & $\stackrel{\mathbb{z}}{z}$ & 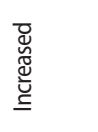 & $\stackrel{\mathbb{z}}{z}$ & $\stackrel{\Sigma}{z}$ & $\stackrel{\Sigma}{z}$ & 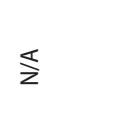 & $\stackrel{\mathbb{z}}{z}$ & 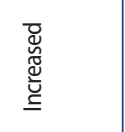 & 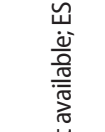 \\
\hline 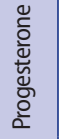 & 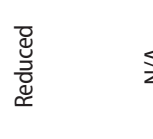 & $\frac{\mathbb{s}}{z}$ & $\frac{\pi}{z}$ & 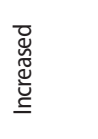 & $\stackrel{s}{z}$ & $\stackrel{\kappa}{z}$ & 蒙 & $\stackrel{\xi}{z}$ & $\underline{z}$ & $\stackrel{\kappa}{z}$ & 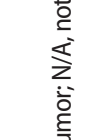 \\
\hline 음 & $\begin{array}{l}\overline{\widetilde{\sigma}} \\
\frac{\bar{g}}{z}\end{array}$ & $\frac{\kappa}{z}$ & $\frac{\mathbb{L}}{z}$ & 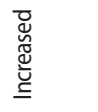 & $\$$ & 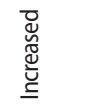 & $\stackrel{s}{z}$ & 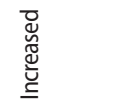 & 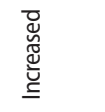 & 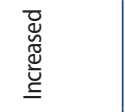 & $\begin{array}{l}\frac{E}{\bar{\Xi}} \\
\overline{\tilde{O}} \\
\underline{\bar{O}}\end{array}$ \\
\hline 这 & $\frac{s}{z}$ & $\frac{\stackrel{0}{\tilde{\nu}}}{2}$ & $\stackrel{\Sigma}{z}$ & $\stackrel{s}{z}$ & $\stackrel{s}{z}$ & 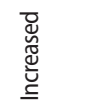 & $\frac{\mathbb{s}}{z}$ & $\stackrel{\Sigma}{z}$ & 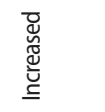 & 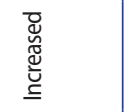 & 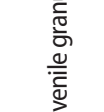 \\
\hline I & 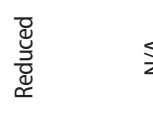 & $\stackrel{\leftarrow}{z}$ & $\stackrel{s}{z}$ & 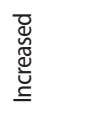 & 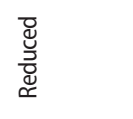 & 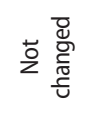 & 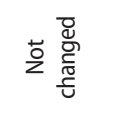 & 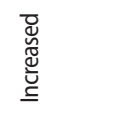 & 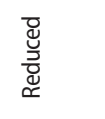 & 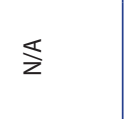 & 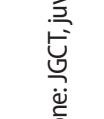 \\
\hline 甹 & 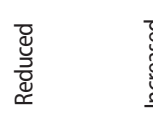 & 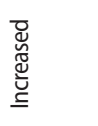 & $\frac{s}{z}$ & $\stackrel{s}{z}$ & 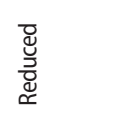 & 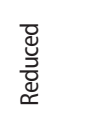 & 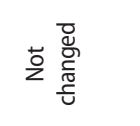 & 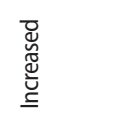 & 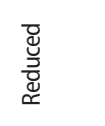 & 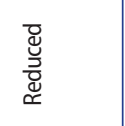 & 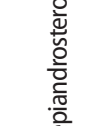 \\
\hline 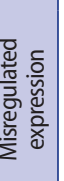 & $\stackrel{\mathbb{z}}{z}$ & 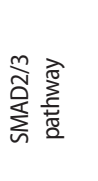 & $\stackrel{\mathbb{z}}{z}$ & $\stackrel{s}{z}$ & 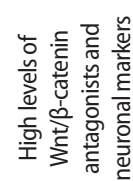 & 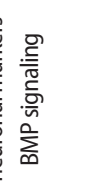 & 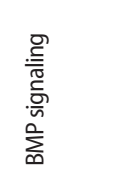 & 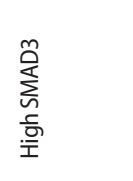 & 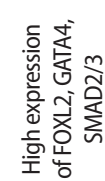 & 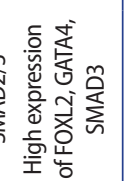 & 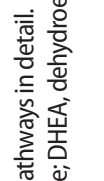 \\
\hline 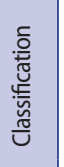 & 늠 & $\frac{\pi}{z}$ & ঢ્ & $\stackrel{\mathbb{z}}{z}$ & 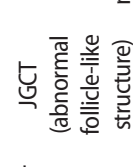 & t. & 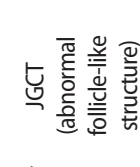 & 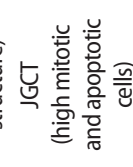 & o & 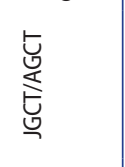 & 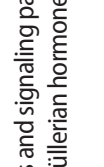 \\
\hline 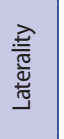 & 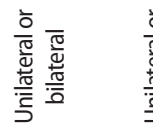 & 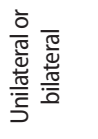 & 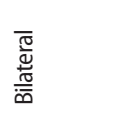 & 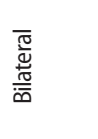 & 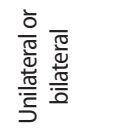 & 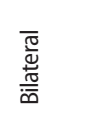 & 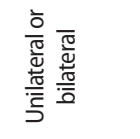 & 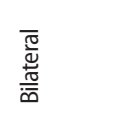 & 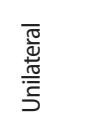 & 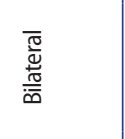 & 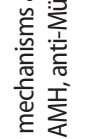 \\
\hline 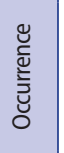 & 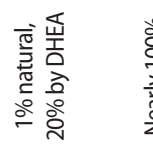 & 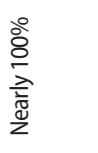 & oे & 胥 & ڤ̊ & ڤ̊ํㅇ & 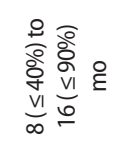 & $\stackrel{8}{\circ}$ & ڤેํㅇ & ஃें & 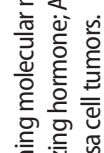 \\
\hline 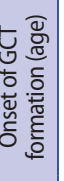 & $\begin{array}{l}\stackrel{y}{3} \\
\stackrel{n}{n} \\
m\end{array}$ & $\underset{f}{3}$ & $\begin{array}{l}\stackrel{0}{\xi} \\
0 \\
1 \\
n\end{array}$ & $\begin{array}{l}\stackrel{0}{E} \\
\infty \\
\mathfrak{d}\end{array}$ & 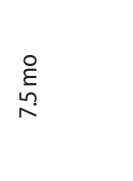 & $\underset{\substack{n \\
n}}{\stackrel{m}{n}}$ & $\underset{\infty}{\stackrel{\ell}{\xi}}$ & 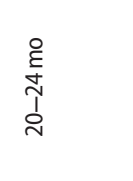 & 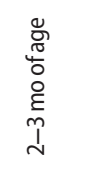 & 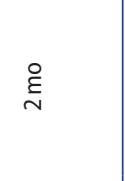 & 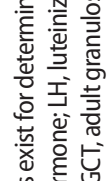 \\
\hline 彥 & 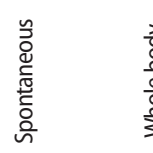 & 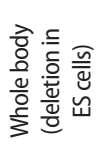 & 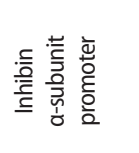 & 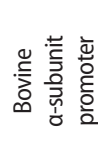 & בั้ & 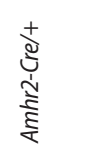 & 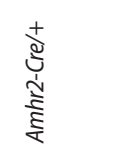 & 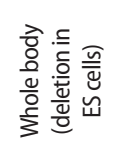 & $\begin{array}{l}+ \\
\stackrel{+}{0} \\
\stackrel{5}{5}\end{array}$ & 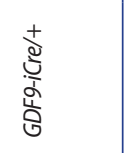 & 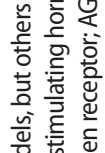 \\
\hline 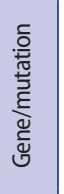 & 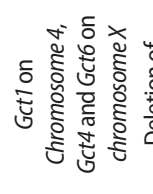 & 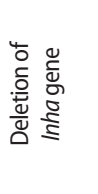 & 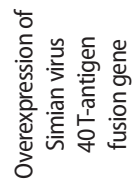 & 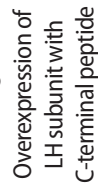 & 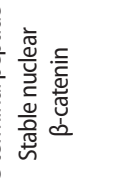 & 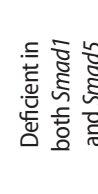 & 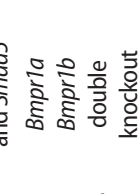 & 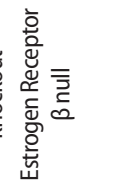 & 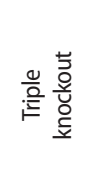 & 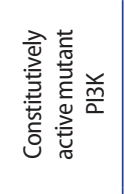 & 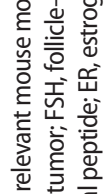 \\
\hline 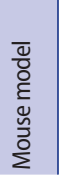 & 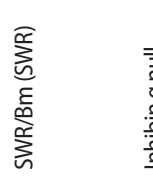 & 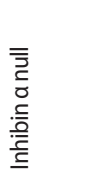 & 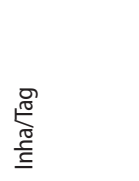 & 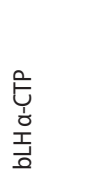 & 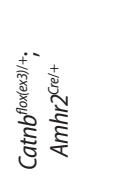 & 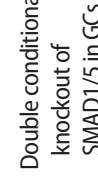 & 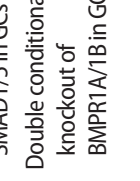 & 旁 & 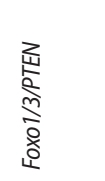 & 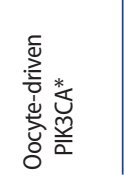 & 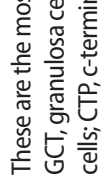 \\
\hline
\end{tabular}


recurrence. Novel mouse models will be useful in answering challenging and persistent questions about GCT etiology. In conclusion, mouse models are powerful tools that aid in understanding the etiology and biological mechanisms driving the initiation and progression of GCTs, as well as help in the development of new detection methods and treatments.

\section{Conflict of interest}

No potential conflict of interest relevant to this article was reported.

\section{Acknowledgments}

I thank Dr. Marilia H. Cordeiro for her helpful suggestions and Stacey Tobin, Megan M. Romero, Alexandra S. Rashedi, and Maxwell E. Edmonds for editing this manuscript.

\section{References}

1. Schumer ST, Cannistra SA. Granulosa cell tumor of the ovary. J Clin Oncol 2003;21:1180-9.

2. Jamieson S, Fuller PJ. Molecular pathogenesis of granulosa cell tumors of the ovary. Endocr Rev 2012;33:109-44.

3. Dilworth JP, Farrow GM, Oesterling JE. Non-germ cell tumors of testis. Urology 1991;37:399-417.

4. Richards JS, Fan HY, Liu Z, Tsoi M, Lague MN, Boyer A, et al. Either Kras activation or Pten loss similarly enhance the dominant-stable CTNNB1-induced genetic program to promote granulosa cell tumor development in the ovary and testis. Oncogene 2012;31:1504-20.

5. Sehouli J, Drescher FS, Mustea A, Elling D, Friedmann W, Kuhn W, et al. Granulosa cell tumor of the ovary: 10 years follow-up data of 65 patients. Anticancer Res 2004;24:1223-9.

6. Colombo N, Parma G, Zanagnolo V, Insinga A. Management of ovarian stromal cell tumors. J Clin Oncol 2007;25:2944-51.

7. Young RH, Dickersin GR, Scully RE. Juvenile granulosa cell tumor of the ovary: a clinicopathological analysis of 125 cases. Am J Surg Pathol 1984;8:575-96.

8. Fox H. Sex cord-stromal tumours of the ovary. J Pathol 1985;145: $127-48$.

9. Lappohn RE, Burger HG, Bouma J, Bangah M, Krans M, de Bruijn HW. Inhibin as a marker for granulosa-cell tumors. N Engl J Med 1989;321:790-3.

10. Jobling T, Mamers P, Healy DL, MacLachlan V, Burger HG, Quinn $\mathrm{M}$, et al. A prospective study of inhibin in granulosa cell tumors of the ovary. Gynecol Oncol 1994;55:285-9.

11. Petraglia F, Luisi S, Pautier P, Sabourin JC, Rey R, Lhomme C, et al.
Inhibin B is the major form of inhibin/activin family secreted by granulosa cell tumors. J Clin Endocrinol Malpb 1998;83:1029-32.

12. Bjorkholm E, Silfversward C. Prognostic factors in granulosa-cell tumors. Gynecol Oncol 1981;11:261-74.

13. Zaloudek C, Norris HJ. Granulosa tumors of the ovary in children: a clinical and pathologic study of 32 cases. Am J Surg Pathol 1982;6:503-12.

14. Shah SP, Kobel M, Senz J, Morin RD, Clarke BA, Wiegand KC, et al. Mutation of FOXL2 in granulosa-cell tumors of the ovary. N Engl J Med 2009;360:2719-29.

15. Jamieson S, Butzow R, Andersson N, Alexiadis M, Unkila-Kallio L, Heikinheimo M, et al. The FOXL2 C134W mutation is characteristic of adult granulosa cell tumors of the ovary. Mod Pathol 2010; 23:1477-85.

16. Kalfa N, Philibert P, Patte C, Ecochard A, Duvillard P, Baldet P, et al. Extinction of FOXL2 expression in aggressive ovarian granulosa cell tumors in children. Fertil Steril 2007;87:896-901.

17. Kim JH, Yoon S, Park M, Park HO, Ko JJ, Lee K, et al. Differential apoptotic activities of wild-type FOXL2 and the adult-type granulosa cell tumor-associated mutant FOXL2 (C134W). Oncogene 2011;30:1653-63.

18. Fleming NI, Knower KC, Lazarus KA, Fuller PJ, Simpson ER, Clyne CD. Aromatase is a direct target of FOXL2: C134W in granulosa cell tumors via a single highly conserved binding site in the ovarian specific promoter. PLoS One 2010;5:e14389.

19. Beysen D, Moumne L, Veitia R, Peters H, Leroy BP, De Paepe A, et al. Missense mutations in the forkhead domain of FOXL2 lead to subcellular mislocalization, protein aggregation and impaired transactivation. Hum Mol Genet 2008;17:2030-8.

20. Benayoun BA, Caburet S, Dipietromaria A, Georges A, D'Haene B, Pandaranayaka PJ, et al. Functional exploration of the adult ovarian granulosa cell tumor-associated somatic FOXL2 mutation p.Cys134Trp (c.402C>G). PLoS One 2010;5:e8789.

21. Kim JH, Kim YH, Kim HM, Park HO, Ha NC, Kim TH, et al. FOXL2 posttranslational modifications mediated by GSK3 $\beta$ determine the growth of granulosa cell tumours. Nat Commun 2014;5:2936.

22. Kalfa N, Ecochard A, Patte C, Duvillard P, Audran F, Pienkowski C, et al. Activating mutations of the stimulatory g protein in juvenile ovarian granulosa cell tumors: a new prognostic factor? J Clin Endocrinol Metab 2006;91:1842-7.

23. Auguste A, Bessiere L, Todeschini AL, Caburet S, Sarnacki S, Prat J, et al. Molecular analyses of juvenile granulosa cell tumors bearing AKT1 mutations provide insights into tumor biology and therapeutic leads. Hum Mol Genet 2015;24:6687-98.

24. Zhang H, Vollmer M, De Geyter M, Litzistorf Y, Ladewig A, Durrenberger $M$, et al. Characterization of an immortalized human granulosa cell line (COV434). Mol Hum Reprod 2000;6:146-53. 
25. Nishi Y, Yanase T, Mu Y, Oba K, Ichino I, Saito M, et al. Establishment and characterization of a steroidogenic human granulosalike tumor cell line, KGN, that expresses functional follicle-stimulating hormone receptor. Endocrinology 2001;142:437-45.

26. Alexiadis $M$, Eriksson $N$, Jamieson $S$, Davis $M$, Drummond $A E$, Chu $S$, et al. Nuclear receptor profiling of ovarian granulosa cell tumors. Horm Cancer 2011;2:157-69.

27. Beamer WG, Hoppe PC, Whitten WK. Spontaneous malignant granulosa cell tumors in ovaries of young SWR mice. Cancer Res 1985;45(11 Pt 2):5575-81.

28. Dorward AM, Yaskowiak ES, Smith KN, Stanford KR, Shultz KL, Beamer WG. Chromosome $X$ loci and spontaneous granulosa cell tumor development in SWR mice: epigenetics and epistasis at work for an ovarian phenotype. Epigenetics 2013;8:184-91.

29. Beamer WG, Shultz KL, Tennent BJ. Induction of ovarian granulosa cell tumors in SWXJ-9 mice with dehydroepiandrosterone. Cancer Res 1988;48:2788-92.

30. Smith KN, Halfyard SJ, Yaskowiak ES, Shultz KL, Beamer WG, Dorward AM. Fine map of the Gct1 spontaneous ovarian granulosa cell tumor locus. Mamm Genome 2013;24:63-71.

31. Beamer WG. Gonadotropin, steroid, and thyroid hormone milieu of young SWR mice bearing spontaneous granulosa cell tumors. J Natl Cancer Inst 1986;77:1117-23.

32. Meunier H, Rivier C, Evans RM, Vale W. Gonadal and extragonadal expression of inhibin alpha, beta $A$, and beta $B$ subunits in various tissues predicts diverse functions. Proc Natl Acad Sci U S A 1988;85:247-51.

33. Kingsley DM. The TGF-beta superfamily: new members, new receptors, and new genetic tests of function in different organisms. Genes Dev 1994;8:133-46.

34. Matzuk MM, Finegold MJ, Su JG, Hsueh AJ, Bradley A. Alpha-inhibin is a tumour-suppressor gene with gonadal specificity in mice. Nature 1992;360:313-9.

35. Kumar TR, Wang Y, Matzuk MM. Gonadotropins are essential modifier factors for gonadal tumor development in inhibin-deficient mice. Endocrinology 1996;137:4210-6.

36. Danilovich N, Roy I, Sairam MR. Ovarian pathology and high incidence of sex cord tumors in follitropin receptor knockout (FORKO) mice. Endocrinology 2001;142:3673-84.

37. Cipriano SC, Chen L, Kumar TR, Matzuk MM. Follistatin is a modulator of gonadal tumor progression and the activin-induced wasting syndrome in inhibin-deficient mice. Endocrinology 2000;141:2319-27.

38. Looyenga BD, Hammer GD. Genetic removal of Smad3 from inhibin-null mice attenuates tumor progression by uncoupling extracellular mitogenic signals from the cell cycle machinery. Mol Endocrinol 2007;21:2440-57.
39. Li Q, Graff JM, O'Connor AE, Loveland KL, Matzuk MM. SMAD3 regulates gonadal tumorigenesis. Mol Endocrinol 2007;21:247286.

40. Rajanahally S, Agno JE, Nalam RL, Weinstein MB, Loveland KL, Matzuk MM, et al. Genetic evidence that SMAD2 is not required for gonadal tumor development in inhibin-deficient mice. Reprod Biol Endocrinol 2010;8:69.

41. Fuller PJ, Chu S. Signalling pathways in the molecular pathogenesis of ovarian granulosa cell tumours. Trends Endocrinol Metab 2004; 15:122-8.

42. Robertson DM, Burger HG, Fuller PJ. Inhibin/activin and ovarian cancer. Endocr Relat Cancer 2004;11:35-49.

43. Kananen K, Markkula M, Rainio E, Su JG, Hsueh AJ, Huhtaniemi IT. Gonadal tumorigenesis in transgenic mice bearing the mouse inhibin alpha-subunit promoter/simian virus T-antigen fusion gene: characterization of ovarian tumors and establishment of gonadotropin-responsive granulosa cell lines. Mol Endocrinol 1995;9:616-27.

44. Dutertre M, Gouedard L, Xavier F, Long WQ, di Clemente N, Picard JY, et al. Ovarian granulosa cell tumors express a functional membrane receptor for anti-Mullerian hormone in transgenic mice. Endocrinology 2001;142:4040-6.

45. Risma KA, Clay CM, Nett TM, Wagner T, Yun J, Nilson JH. Targeted overexpression of luteinizing hormone in transgenic mice leads to infertility, polycystic ovaries, and ovarian tumors. Proc Natl Acad Sci U S A 1995;92:1322-6.

46. Keri RA, Lozada KL, Abdul-Karim FW, Nadeau JH, Nilson JH. Luteinizing hormone induction of ovarian tumors: oligogenic differences between mouse strains dictates tumor disposition. Proc Natl Acad Sci U S A 2000;97:383-7.

47. Lapthorn AJ, Harris DC, Littlejohn A, Lustbader JW, Canfield RE, Machin KJ, et al. Crystal structure of human chorionic gonadotropin. Nature 1994;369:455-61.

48. Nagaraja AK, Agno JE, Kumar TR, Matzuk MM. Luteinizing hormone promotes gonadal tumorigenesis in inhibin-deficient mice. Mol Cell Endocrinol 2008;294:19-28.

49. Mikola M, Kero J, Nilson JH, Keri RA, Poutanen M, Huhtaniemi I. High levels of luteinizing hormone analog stimulate gonadal and adrenal tumorigenesis in mice transgenic for the mouse inhibin-alpha-subunit promoter/Simian virus 40 T-antigen fusion gene. Oncogene 2003;22:3269-78.

50. Cross DA, Alessi DR, Cohen P, Andjelkovich M, Hemmings BA. Inhibition of glycogen synthase kinase-3 by insulin mediated by protein kinase B. Nature 1995;378:785-9.

51. Boyer A, Goff AK, Boerboom D. WNT signaling in ovarian follicle biology and tumorigenesis. Trends Endocrinol Metab 2010;21:2532. 
52. Vainio S, Heikkila M, Kispert A, Chin N, McMahon AP. Female development in mammals is regulated by Wnt-4 signalling. Nature 1999;397:405-9.

53. Hsieh M, Boerboom D, Shimada M, Lo Y, Parlow AF, Luhmann UF, et al. Mice null for Frizzled4 (Fzd4-/-) are infertile and exhibit impaired corpora lutea formation and function. Biol Reprod 2005; 73:1135-46.

54. Abedini A, Zamberlam G, Lapointe E, Tourigny C, Boyer A, Paquet $M$, et al. WNT5a is required for normal ovarian follicle development and antagonizes gonadotropin responsiveness in granulosa cells by suppressing canonical WNT signaling. FASEB J 2015 Dec 14 [Epub]. http://dx.doi.org/10.1096/fj.15-280313.

55. Lapointe E, Boerboom D. WNT signaling and the regulation of ovarian steroidogenesis. Front Biosci (Schol Ed) 2011;3:276-85.

56. Boerboom D, Paquet M, Hsieh M, Liu J, Jamin SP, Behringer RR, et al. Misregulated Wnt/beta-catenin signaling leads to ovarian granulosa cell tumor development. Cancer Res 2005;65:920615.

57. Boerboom D, White LD, Dalle S, Courty J, Richards JS. Dominantstable beta-catenin expression causes cell fate alterations and Wnt signaling antagonist expression in a murine granulosa cell tumor model. Cancer Res 2006;66:1964-73.

58. Lague MN, Paquet M, Fan HY, Kaartinen MJ, Chu S, Jamin SP, et al. Synergistic effects of Pten loss and WNT/CTNNB1 signaling pathway activation in ovarian granulosa cell tumor development and progression. Carcinogenesis 2008;29:2062-72.

59. Pangas SA, Li X, Umans L, Zwijsen A, Huylebroeck D, Gutierrez C, et al. Conditional deletion of Smad1 and Smad5 in somatic cells of male and female gonads leads to metastatic tumor development in mice. Mol Cell Biol 2008;28:248-57.

60. Middlebrook BS, Eldin K, Li X, Shivasankaran S, Pangas SA. Smad1-Smad5 ovarian conditional knockout mice develop a disease profile similar to the juvenile form of human granulosa cell tumors. Endocrinology 2009;150:5208-17.

61. Mansouri-Attia N, Tripurani SK, Gokul N, Piard H, Anderson ML, Eldin $\mathrm{K}$, et al. TGF $\beta$ signaling promotes juvenile granulosa cell tumorigenesis by suppressing apoptosis. Mol Endocrinol 2014;28:
1887-98.

62. Erickson GF, Shimasaki S. The spatiotemporal expression pattern of the bone morphogenetic protein family in rat ovary cell types during the estrous cycle. Reprod Biol Endocrinol 2003;1:9.

63. Edson MA, Nalam RL, Clementi C, Franco HL, Demayo FJ, Lyons KM, et al. Granulosa cell-expressed BMPR1A and BMPR1B have unique functions in regulating fertility but act redundantly to suppress ovarian tumor development. Mol Endocrinol 2010;24:125166.

64. Fan X, Gabbi C, Kim HJ, Cheng G, Andersson LC, Warner M, et al. Gonadotropin-positive pituitary tumors accompanied by ovarian tumors in aging female ERbeta-/- mice. Proc Natl Acad Sci U S A 2010;107:6453-8.

65. Couse JF, Korach KS. Estrogen receptor null mice: what have we learned and where will they lead us? Endocr Rev 1999;20:358417.

66. Burns KH, Agno JE, Chen L, Haupt B, Ogbonna SC, Korach KS, et al. Sexually dimorphic roles of steroid hormone receptor signaling in gonadal tumorigenesis. Mol Endocrinol 2003;17:2039-52.

67. Fan HY, Liu Z, Cahill N, Richards JS. Targeted disruption of Pten in ovarian granulosa cells enhances ovulation and extends the life span of luteal cells. Mol Endocrinol 2008;22:2128-40.

68. Liu Z, Ren YA, Pangas SA, Adams J, Zhou W, Castrillon DH, et al. FOX01/3 and PTEN depletion in granulosa cells promotes ovarian granulosa cell tumor development. Mol Endocrinol 2015;29:100624.

69. Lan ZJ, Xu X, Cooney AJ. Differential oocyte-specific expression of Cre recombinase activity in GDF-9-iCre, Zp3cre, and Msx2Cre transgenic mice. Biol Reprod 2004;71:1469-74.

70. Kim SY, Ebbert K, Cordeiro MH, Romero M, Zhu J, Serna VA, et al. Cell autonomous phosphoinositide 3-kinase activation in oocytes disrupts normal ovarian function through promoting survival and overgrowth of ovarian follicles. Endocrinology 2015;156:1464-76.

71. Kim SY, Ebbert K, Cordeiro M, Romero M, Whelan KA, Woodruff $\mathrm{TK}$, et al. Oocyte-driven granulosa cell tumorigenesis in mouse ovary. Proceedings of ENDO 2016; 2016 April 3; Boston, MA. 